\title{
25. PHYSICAL PROPERTIES OF SEDIMENTS AND BASALTS FROM SITES 353, 354, AND 355, DSDP LEG 39
}

\author{
Yu. P. Neprochnov and E.G. Mirlin, Institute of Oceanology, USSR Academy of Sciences, Moscow \\ and \\ B.P. Belikov, Institute of Geology of Ore Deposits, Petrography, Mineralogy and Geochemistry,
}

USSR Academy of Sciences, Moscow

\section{INTRODUCTION}

Physical properties of the sediments (density, porosity, water content, sound velocity) were determined onboard Glomar Challenger. Methods of measurement and main results are given in the site reports. Here, a detailed analysis of the long stratigraphic sequence at Site 354 is given in order to characterize the carbonate sediments and to compare their properties with the pelagic clay of Site 355 .

Preliminary determinations of the physical properties of basalts from Sites 353, 354, and 355 were done onboard Glomar Challenger. More detailed measurements were made at the Physical-Mechanical Laboratory of the Institute of Geology of Ore Deposits, Petrography, Mineralogy, and Geochemistry, USSR Academy of Sciences. Density, porosity, and elastic modulus (compressional and shear wave velocities) were measured on cylindrical samples (length about 20 $\mathrm{mm}$, diameter $30 \mathrm{~mm}$ ). Densities were determined by using the hydrostatic method, and porosity by water filling (Belikov et al., 1964); velocities were measured at frequencies of 1.57 and $5.0 \mathrm{mHz}$ (Aleksandrov and Novikov, 1956). Magnetic properties of basalts and their dependence on temperature were studied at the Institute of Oceanology and the Institute of Physics of the Earth, USSR Academy of Sciences.

\section{PHYSICAL PROPERTIES OF SEDIMENTS}

\section{Site 354}

Five to ten measurements of the compressional wave velocity were usually made for every 1.5 -meter section of drill cores. The averages of these measurements, along with density, are shown in Figure 1. Note that densities for Cores 6 to 12 were determined indirectly from water content by using the linear dependence between density and water content observed in Cores 1 to 5 (Carlson's shipboard measurements).

Compressional wave velocity in the sediments increases from $1500 \mathrm{~m} / \mathrm{sec}$ at a depth of 100 meters to $2570 \mathrm{~m} / \mathrm{sec}$ at 880 meters, giving an average vertical gradient of velocity of $1.29 \mathrm{sec}^{-1}$. Velocity decreases at a depth of about 200 meters; the velocity gradient increases in the depth intervals between 200 and 340 meters and 530 to 700 meters (Figure 1).

Density increases comparatively quickly from 1.65 $\mathrm{g} / \mathrm{cm}^{3}$ at 100 meters to $1.90 \mathrm{~g} / \mathrm{cm}^{3}$ at 240 meters, and

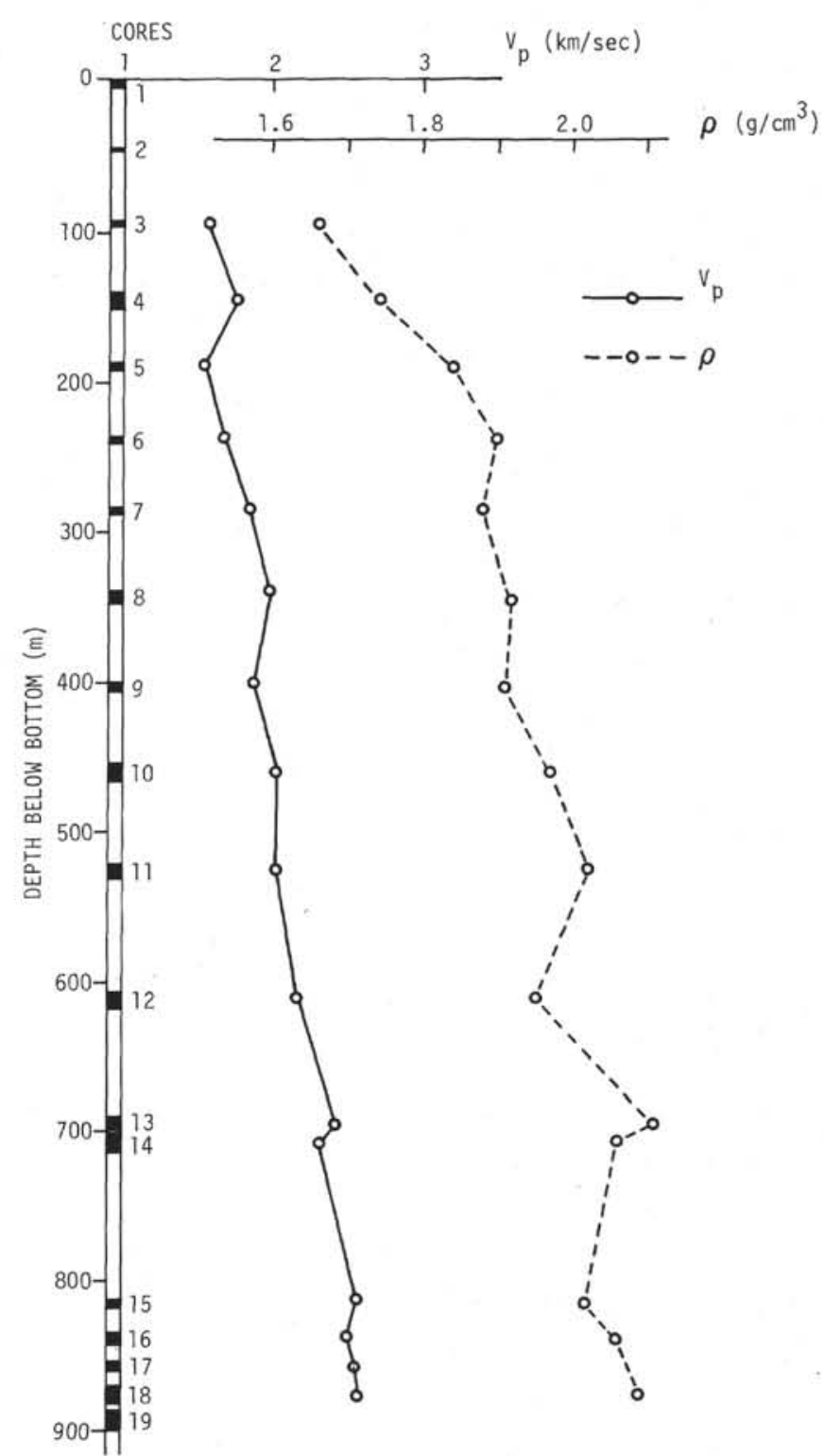

Figure 1. Measured velocities and densities of sediments at Site 354 (shipboard data).

reaches $2.10 \mathrm{~g} / \mathrm{cm}^{3}$ at the base of the sedimentary section.

A comparison between physical properties and lithology (see the lithological description of Site 354) 
shows that the decrease of velocity at 200 meters may be associated with the transition between nannofossil ooze and chalk and with an increase in clay. Below this depth lithology changes slowly with depth: chalk grades into marly chalk with attendant increase in density and velocity. Maximum values of density and velocity were measured in hard marly chalk and from the lower part of the sequence.

\section{Site 355}

Measured velocities at Site 355, made onboard by $R$. Carlson (Figure 2), are noticeably lower than velocities at Site 354; we attribute this to lithological differences. In the interval from 50 to 350 meters sonic velocity slowly increases with depth (from 1500 to $1620 \mathrm{~m} / \mathrm{sec}$ ); the average vertical gradient of the velocity is $0.4 \mathrm{sec}^{-1}$. The sediments here consist mainly of pelagic oozes and clays (see the lithological description of Site 355). Deeper, the velocity gradient increases; this may be explained by the higher proportion of carbonate and silicate (Cores 7 to 11 ). In the interval from 420 meters,

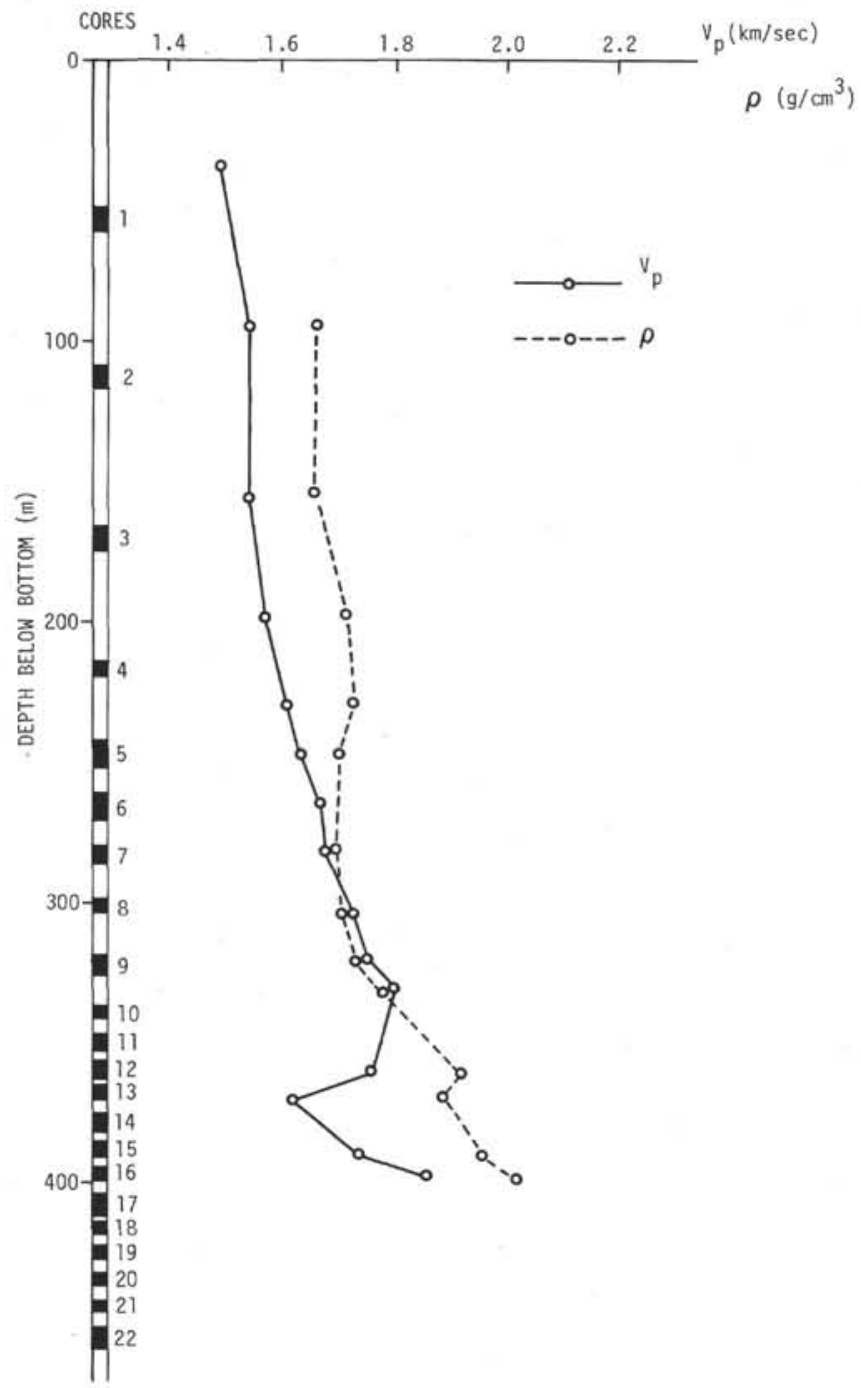

Figure 2. Measured velocities and densities of sediments at Site 355 (shipboard data). which consists of mudstone and claystone, velocity reaches $1750-1870 \mathrm{~m} / \mathrm{sec}$. The density of sediments down to a depth of 340 meters is comparatively low $\left(1.67\right.$ to $\left.1.75 \mathrm{~g} / \mathrm{cm}^{3}\right)$. Values increase to $1.90-2.04 \mathrm{~g} / \mathrm{cm}^{3}$ in the lower part of the column.

Comparison of the results of sonic velocity measurements for Sites 354 and 355 shows that calcareous sediments are characterized by higher velocities, densities, and vertical gradients of velocity than clayey pelagic sediments.

\section{PHYSICAL PROPERTIES OF BASALTS}

Determinations of density, porosity, and elastic properties on basalt samples from Holes 353A, 353B, 354 , and 355 are given in Table 1. Photomicrographs of these rocks show that they differ in structure. The Site 353 (Vema Fracture Zone) rock is an aphanitic basalt glass; at Site 354 (Ceará Rise) it is holocrystalline, fine to medium grained basalts; at Site 355 (Brazil Basin) it is vitric basalt.

The density and elastic properties of the basalts are different because of different porosities. The rocks from Sites 353 and 355 have average porosities of $3 \%-4 \%$ and compressional wave velocity about $6 \mathrm{~km} / \mathrm{sec}$, typical of basic rocks (Birch, 1961; Belikov et al., 1970). The basalts from Site 354, with an average porosity of about $7.5 \%$, are characterized by lower velocity, about 5 $\mathrm{km} / \mathrm{sec}$.

Site 354 was drilled to a depth of about 9 meters into basalt. A number of samples from this site were used to plot the change of the physical properties with depth (Figure 3). These plots clearly show the connection between porosity, density, and elastic properties on the one hand, and the crystalline structure of the basalt on the other. At the top and base of the basalt layer porosity is higher and the compressional wave velocity is lower by more than $1 \mathrm{~km} / \mathrm{sec}$ compared to the middle part of the layer. The same relationship is seen for the shear wave velocity and is also illustrated by Poisson's ratio.

Results of measurement of natural residual magnetism in basalts are given in Table 2 . The basalts from

TABLE 1

Density $\rho$, Porosity $m$, Compressional $V_{p}$ and Shear $V_{s}$ Wave Velocity, and Poisson's Ratio of Basalts

\begin{tabular}{llllll}
\hline $\begin{array}{c}\text { Sample } \\
\text { (Interval in cm) }\end{array}$ & $\begin{array}{c}\rho \\
\left(\mathrm{g} / \mathrm{cm}^{3}\right)\end{array}$ & $\begin{array}{c}m \\
(\%)\end{array}$ & $\begin{array}{c}V_{p} \\
(\mathrm{~km} / \mathrm{sec})\end{array}$ & $\begin{array}{c}V_{s} \\
\text { Roisson's } \\
\text { Ratio }\end{array}$ \\
\hline 353A-1-2, 3-5 & 2.808 & 5.66 & 5.85 & 3.32 & 0.26 \\
353B-1-1, 5-7 & 2.838 & 4.20 & 5.99 & 3.32 & 0.28 \\
353B-1-1, 12-15 & 2.870 & 2.93 & 5.99 & 3.39 & 0.27 \\
353B-1-1, 18-20 & 2.885 & 3.16 & 5.96 & 3.42 & 0.25 \\
354-19-1,13-15 & 2.576 & 11.87 & 4.17 & 2.46 & 0.24 \\
354-19-2,146-148 & 2.667 & 7.12 & 5.13 & 2.94 & 0.25 \\
354-19-3,19-21 & 2.632 & 8.20 & 4.89 & 2.83 & 0.25 \\
$354-19-3,140-142$ & 2.722 & 5.49 & 5.34 & 3.00 & 0.27 \\
$354-19-4,68-73$ & 2.685 & 5.78 & 5.21 & 2.96 & 0.26 \\
$354-19-4,79-81$ & 2.710 & 5.23 & 5.43 & 3.04 & 0.27 \\
$354-19-5,67-69$ & 2.737 & 5.86 & 5.35 & 3.04 & 0.26 \\
$354-19-6,3-5$ & 2.656 & 9.31 & 4.79 & 2.75 & 0.25 \\
$354-19-6,99-101$ & 2.688 & 8.18 & 4.87 & 2.80 & 0.25 \\
\hline
\end{tabular}




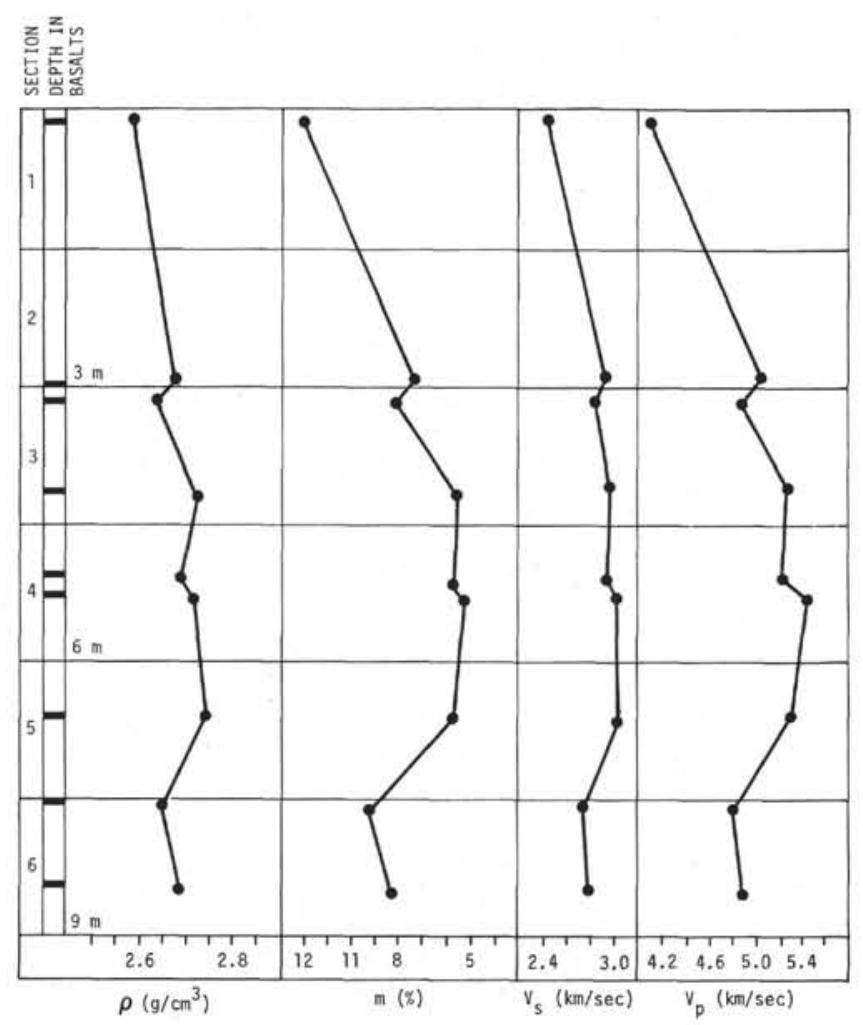

Figure 3. Density $\rho$, porosity $\mathrm{m}$, compressional $\mathrm{V}_{\mathrm{p}}$, and shear $\mathrm{V}_{\mathrm{s}}$ wave velocity for basalts at Site 354, Core 19.

Site 353 are most intensely magnetized. The basalts from Site 354 are characterized by a marked change of magnetism with depth: the samples from the top and base of the layer have higher magnetization compared to the samples from the middle part of the basalt layer (Figure 4). Thermomagnetic data are given in Figure 5 as curves of residual magnetization $I_{r s}\left(t^{\circ}\right)$. Thermomagnetic characteristics are similar within each site. For example, for the samples from Site 354, note the
TABLE 2

Natural Residual Magnetism of Basalts

\begin{tabular}{lc}
\hline $\begin{array}{c}\text { Sample } \\
\text { (Interval in cm) }\end{array}$ & $\begin{array}{c}\text { Residual magnetism } \\
\text { (x 10-6 }\end{array}$ \\
\hline 35SM units)
\end{tabular}

similarity of the $I_{r s}\left(t^{\circ}\right)$ curves, the closeness of Curie points and the increase of $I_{r s}$ after the first and second heating (Figures $5 \mathrm{a}, \mathrm{b}$ ). The $I_{r s}$ curves for Site 354 belong to a type which characterizes rocks with lowtemperature titanum magnetite (Perchersky et al., 1975).

Thermomagnetic characteristics of the samples from Site 353 are different from those of Site 354 (Figures 5c, d). Their Curie points are compartively low $\left(170^{\circ}\right.$ $250^{\circ} \mathrm{C}$ ). Curves of $I_{r s} 1$ and $I_{r s} 2$ are typical for low oxidizing titanum magnetite which is contained in basic effusive rocks (Perchersky et al., 1975).

The depth dependence of density, porosity, elastic and magnetic properties for basalts at Site 354 may indicate a comparatively thin lava flow, or perhaps a sill.

\section{REFERENCES}

Aleksandrov, K.S. and Novikov, O.V., 1956. Appartus for the measurements of elastic modules of crystals: Acoustic, No. 31, Moscow.

Belikov, B.P., Zalessky, B.V., Rozanov, Yu. A., Savina, E.A., and Timchenko, I.P., 1964. Methods of physical-

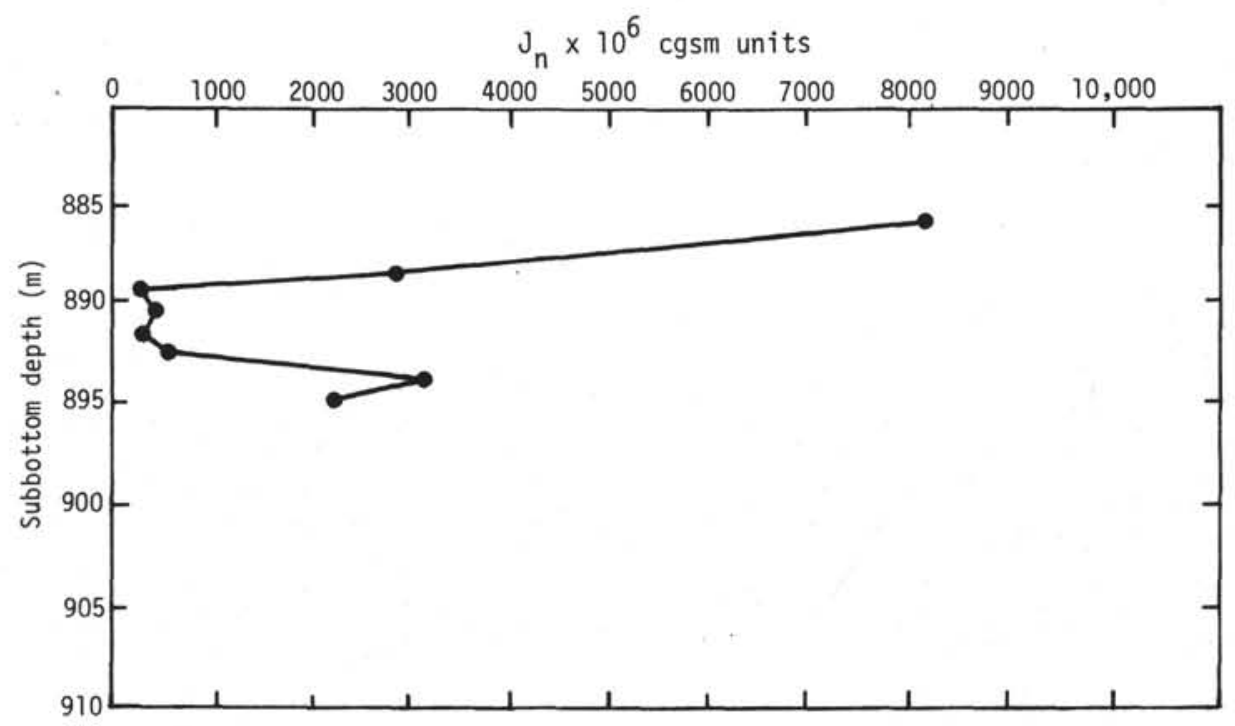

Figure 4. Residual magnetism of basalts from Site 354. 

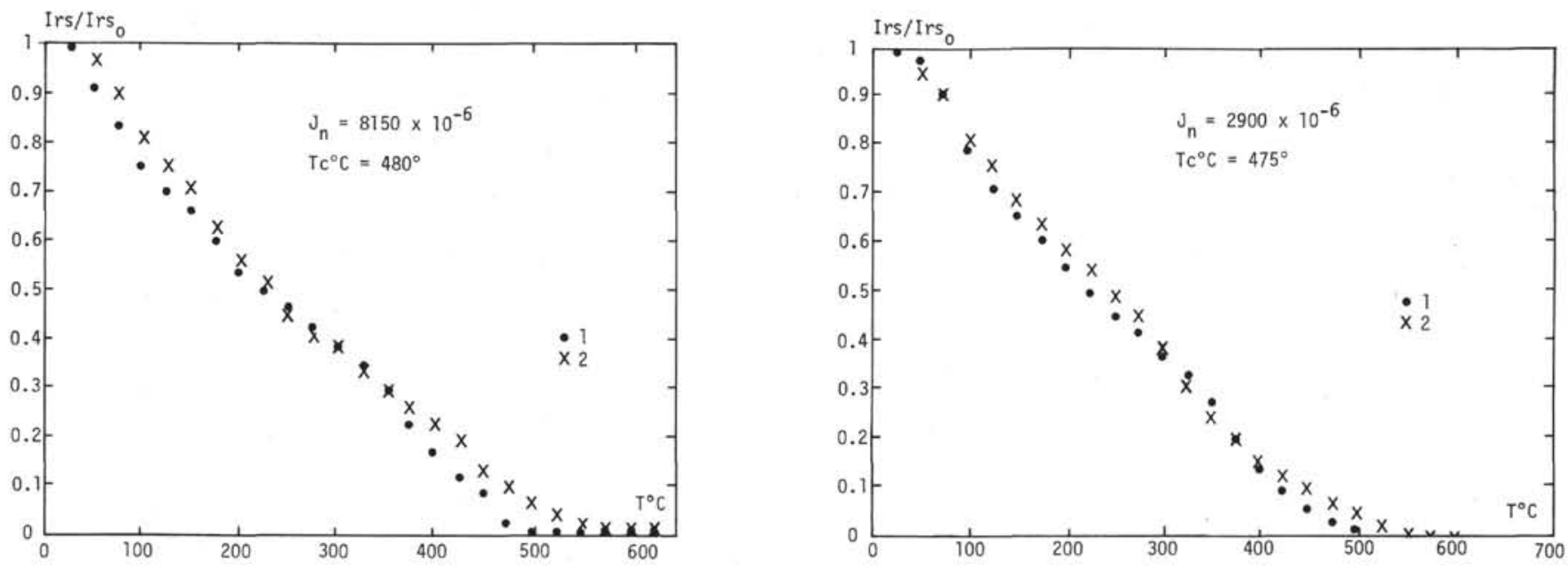

B


Figure 5. Thermomagnetic curves $\mathrm{I}_{\mathrm{rs}}\left(\mathrm{t}^{\circ}\right)$ of basalts. (A) Sample 354-19-1, 13-15 cm; (B) Sample 354-19-2, 146-148 cm; (C) Sample 353B-1-1, 18-20 cm; (D) Sample 353B-1-1, 5-7 cm; 1 and 2 correspond to the first and second heating.

mechanical study of rocks. In Physical and mechanical properties of rocks: Moscow (Nauka).

Belikov, B.P., Aleksandrov, K.S., and Rychova, P.V., 1970. The elastic properties of the rock constituents minerals and rocks: Moscow (Nauka).
Birch, F., 1961. The velocity of compressional waves in rocks to 10 kilobars. Part 2: J. Geophys. Res., v. 66.

Pechersky, D.M., Bagin, B.I., Brodskaya, S. Yu., and Sharonova, Z.V., 1975. Magnetism and the conditions of origin of intrusive rocks: Moscow (Nauka). 